\title{
Analysis and Assessment of Hydrochemical Characteristics of Maragheh-Bonab Plain Aquifer, Northwest of Iran
}

\author{
Elham Fijani ${ }^{1}$ - Asghar Asghari Moghaddam ${ }^{2}$. \\ Frank T.-C. Tsai ${ }^{3} \cdot$ Gokmen Tayfur $^{4}$
}

Received: 20 April 2016 / Accepted: 1 June 2016 /

Published online: 6 June 2016

(C) Springer Science+Business Media Dordrecht 2016

\begin{abstract}
The present study aims at assessing the hydrochemistry of the groundwater system of the Maragheh-Bonab Plain located in the East Azarbaijan Province, northwest of Iran. The groundwater is used mainly for drinking, agriculture and industry. The study also discusses the issue of the industrial untreated wastewater discharge to the Plain aquifer that is a high $\mathrm{Ca}-\mathrm{Cl}$ water type with TDS value of about $150 \mathrm{~g} / \mathrm{L}$. The hydrogeochemical study is conducted by collecting and analyzing the groundwater samples from July and September of 2013. The studied system contains three major groundwater types, namely $\mathrm{Ca}-\mathrm{Mg}-\mathrm{HCO}_{3}, \mathrm{Na}-\mathrm{Cl}$, and non-dominant water, based on the analysis of the major ions. The main processes contributing to chemical compositions in the groundwater are the dissolution along the flow path, dedolomitisation, ion exchange reactions, and the mixing with wastewater. According to the computed water quality index (WQI) ranging from 25.45 to 194.35 , the groundwater in the plain can be categorized into "excellent water", "good water", and "poor water". There is a resemblance between the spatial distribution of the WQI and hydrochemical water types in the Piper diagram. The "excellent" quality water broadly coincides with the $\mathrm{Ca}-\mathrm{Mg}-\mathrm{HCO}_{3}$ water type. The "poor" water matches with the $\mathrm{Na}-\mathrm{Cl}$ water type, and the "good" quality water coincides with blended water. The results indicate that this aquifer suffers from intense human activities which are forcing the aquifer into a critical condition.
\end{abstract}

Key Words Maragheh-Bonab plain · Urmia Lake $\cdot$ Hydrochemical evolution $\cdot$ Hydrochemical processes - Water quality index

\section{Elham Fijani}

Efijani@ut.ac.ir

1 School of Geology, College of Science, University of Tehran, Tehran, Iran

2 Department of Geology, Faculty of Natural Science, University of Tabriz, Tabriz, Iran

3 Department of Civil and Environmental Engineering, Louisiana State University, Baton Rouge, LA, USA

4 Department of Civil Engineering, Izmir Institute of Technology, Urla, Izmir, Turkey 


\section{Introduction}

Groundwater is the main water source for actual uses in the Maragheh-Bonab Plain, Iran, which is located in semi-arid and arid areas (Fig. 1). The groundwater in this plain is vital to local people as a water supply for the public, industry, and irrigation in the plain. Evaluation and management of groundwater resources require an understanding of the hydrogeological and hydrochemical properties of the aquifer (Umar et al. 2001) since these parameters control groundwater occurrence, quantity and quality (Freeze and Cherry 1979; Hossain et al. 2010). Groundwater quality depends not only on natural factors such as aquifer lithology (Acheampong and Hess 1998; Umar et al. 2001; Kortatsi 2007; Umar et al. 2009), quality of recharge water and interaction with other types of water, but also on human activities that can deteriorate the aquifer system by pollution (Jiang et al. 2009; Ravikumar et al. 2010).

Recent research showed the importance of investigating the impacts of various factors on hydrogeochemistry (Dragon 2006; Cloutier et al. 2008; Morgenstern et al. 2015; Huang et al. 2015). For groundwater resource management, many studies have been conducted on hydrochemical framework (Acheampong and Hess 1998; Umar et al. 2001; Kortatsi 2007; Umar et al. 2009). Acheampong and Hess (1998) used hydrogeologic and hydrochemical framework to study and understand the relationship between groundwater chemistry, geology, and its flow system in southern Voltaian Sedimentary Basin, Ghana. Umar et al. (2001) presented hydrogeologic and hydrochemical framework of the Ganga basin in India by describing hydrological characteristics and quality assessment. Asghari Moghaddam and Fijani (2009) studied the hydrogeologic framework and water quality to investigate the effect of basaltic formation on groundwater resources in the Maku area, Iran. Research also was carried out by Ravikumar et al. (2010) to assess the effects of natural and anthropogenic activities on groundwater quality using major ion chemistry.

Water quality index (WQI) is an effective tool to obtain a comprehensive picture of the quality of groundwater (Tiwari and Mishra 1985; Singh 1992; Subba Rao 1997; Mishra and Patel 2001). The WQI was developed in the 1970s by Oregon Department of Environmental Quality for the purpose of summarizing and evaluating water quality trend and status (Dunnette 1979; Rajankar et al. 2011). Vasanthavigar et al. (2010) did research to understand the hydrogeochemical parameters for developing a water quality index in the Thirumanimuttar

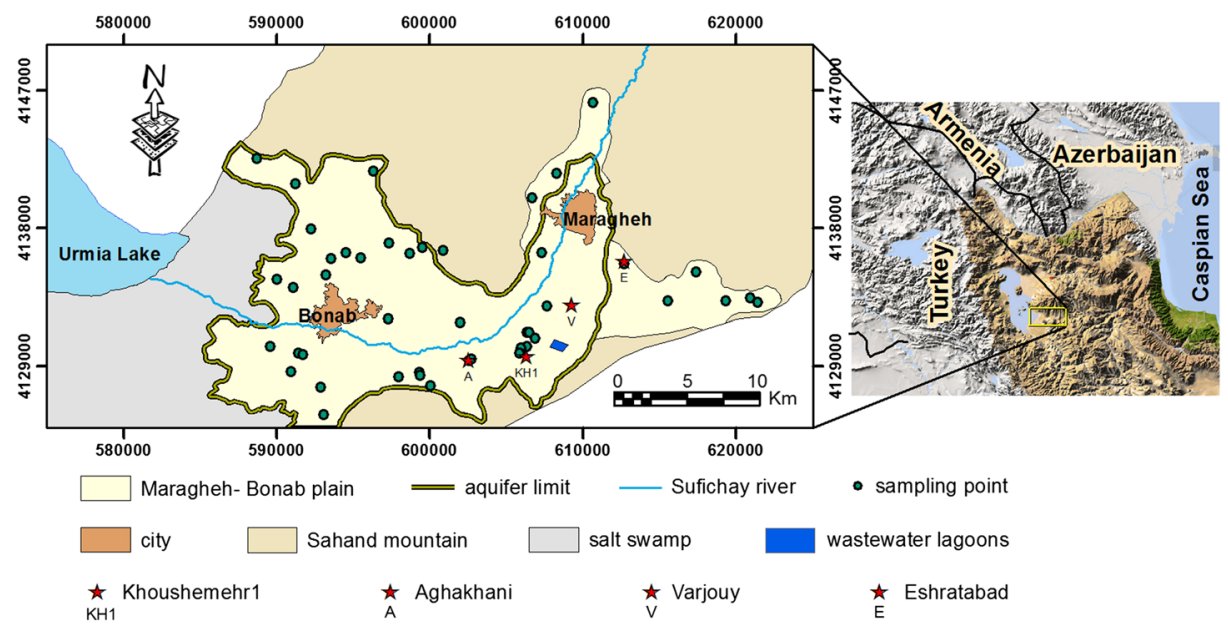

Fig. 1 Location of the study area 
subbasin. Rajankar et al. (2011) presented the results of a monitoring study focusing on groundwater quality of the Bhandara District in central India using water quality index.

The first study on groundwater resources in the Maragheh-Bonab Plain began in 1964 by the Water Resource Corporation of East Azarbaijan Province. During that study, groundwater sampling, paper base maps, and exploratory investigations were prepared. A geophysical survey was carried out using geoelectrical methods by the Water and Soil Consulting Corporation in 1975. A number of reports were published by the Water Resource Corporation of East Azarbaijan Province in Persian based on regular water sampling and measurements in the study area.

To achieve a better understanding of the Maragheh-Bonab groundwater system, the objectives of this study are defined as: 1) identification of the groundwater types and sources of probable anomalies; 2) determination of the hydrochemical processes and groundwater evolution; 3) investigation of the effect of industrial activities on hydrochemistry; and 4) determination of the water quality index and suitability of groundwater.

\section{Description of the Study Area}

The study area shown in Fig. 1 comprises of southern part of the East Azerbaijan province, northwest of Iran, occupying approximately $1000 \mathrm{~km}^{2}$. Maragheh-Bonab plain with an area of about $330 \mathrm{~km}^{2}$ is located in south of Tabriz and east of Urmia lake. This plain is considered as an arid and cold area, according to Amberge method, with the average annual precipitation and the mean annual temperature as $345.7 \mathrm{~mm}$ and $13.1{ }^{\circ} \mathrm{C}$, respectively, for a 10-year period (2004-2014) in Maragheh station (reported by Iranian Meteorological Organization). The average annual precipitation in the Maragheh-Bonab plain and surrounding mountainous area is 279 and $364 \mathrm{~mm}$, respectively. The annual potential evaporation is $1444 \mathrm{~mm}$, which is several times higher than the average annual precipitation. This is likely to justify the water deficit in some parts of the basin. The average annual relative humidity during the year is about $50 \%$ (Fijani et al. 2013).

The Sufichay River shown in Fig. 1 is the main river in the study area, which originates from the southern hills of Sahand Mountain. The river flows in the southwest direction and enters the city of Maragheh. The flow path, then changes to the west, entering farmlands in the city of Bonab, and finally discharges into Urmia Lake.

\subsection{Geological Setting}

The Maragheh-Bonab Plain is, structurally, a part of the Central zone of Iran (Stocklin 1968; Berberian and King 1981). The geological map of the study area is depicted in Fig. 2. This area includes formations of the Precambrian to the Quaternary age with some stratigraphic gaps and the geology of the area mainly consists of Jurassic, Cretaceous and Cenozoic rocks (Alavi and Shahrabi 1978). Outcrops of Precambrian formations include red sandstone of Lalun Formation and shale, dolomite, and limestone of Mila Formation, which were observed in the west of the mountainous area. The oldest rocks of Mesozoic are known as dolomites of Elika Formation of Triassic age, which exist in a lesser extent compared to Precambrian formations. Jurassic deposits consist of shale and sandstone of Shemshak Formation, dolomites of Delichay Formation, and limestone of Lar Formation outcrops in the north of the mountainous area. Cretaceous rocks with limestone facies mainly exist in the southern mountainous area. Also, the study area mainly consists of the extended consolidated deposits of Sahand tuff, claystone and Maragheh boney layers, known as Maragheh 

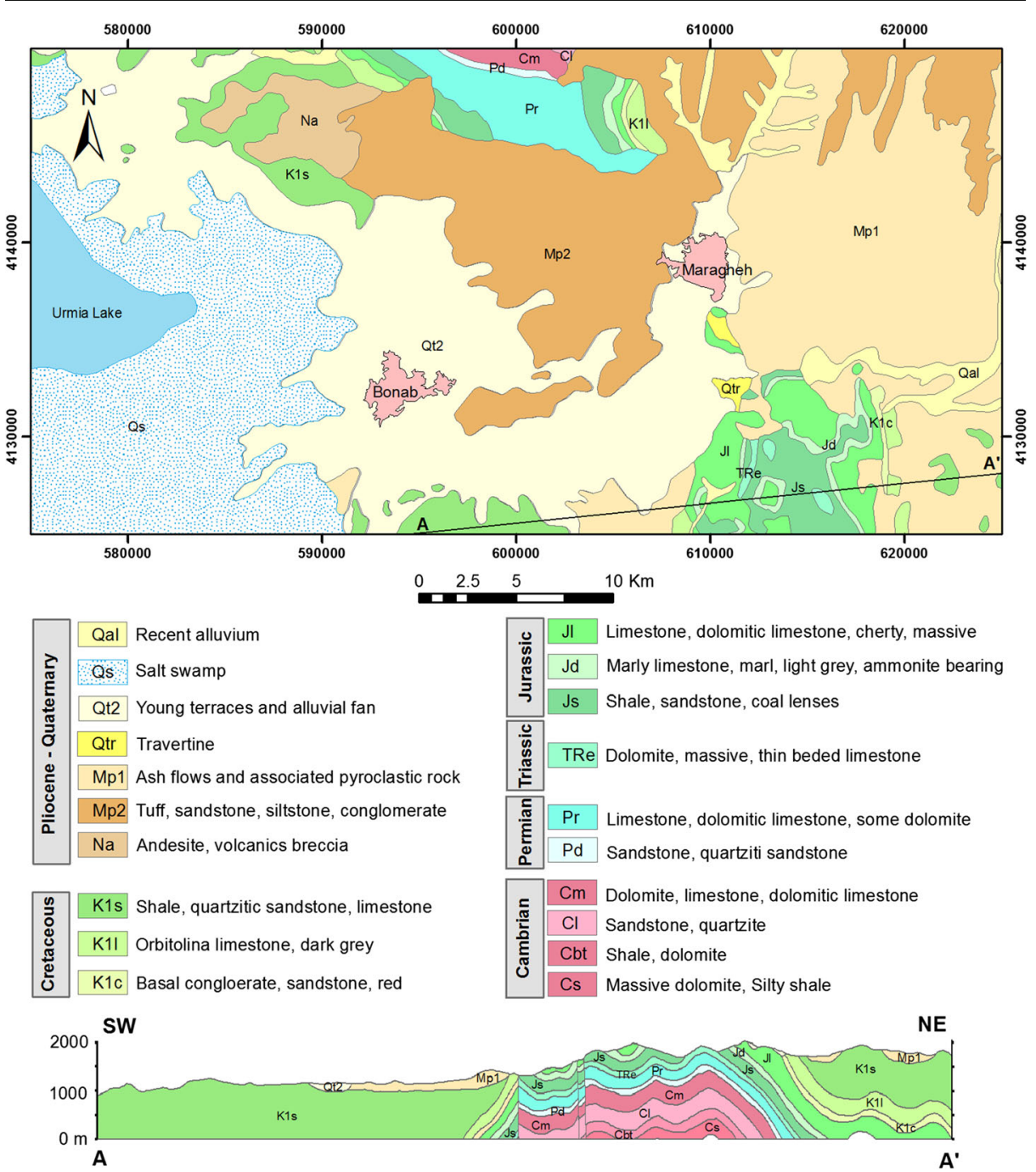

Fig. 2 Geological map of the study area (map modified from Alavi and Shahrabi 1978)

group that covers throughout the mountainous area and the southern highlands in the vicinity of Cretaceous outcrops (Campbell et al. 1980). Quaternary deposits cover most of the foothill lands and the plain including farmlands. The geological cross section is shown in Fig. 2.

\subsection{Hydrogeology}

Based on geophysical explorations and the data collected from observation wells, the Maragheh-Bonab Plain aquifer is recognized as an unconfined, one layer aquifer and the bedrock is composed of clay and marl. Concerning the hydrogeology of the study area, permeable formations mostly comprise of alluvial sediments, including fluvial deposits (Qal), debris sediments (Qt2 \& Q1), and the elevated terrace (Qt1) of Quaternary age. Among fractured rocks around the Maragheh-Bonab plain that largely occur in the highlands, 
Permian limestone formations have a high permeability in the northern area, but they are not very widespread. Jurassic formations have moderate permeability, whereas the Maragheh group and the other formations have low permeability (Fijani et al. 2013). The aquifer is replenished by precipitation, irrigation, and rivers. Transmissivity varies in the area since the aquifer thickness and grain size are different in various areas of the plain. According to the Water Resource Corporation of East Azarbaijan, the maximum transmissivity value is $2500 \mathrm{~m}^{2} / \mathrm{d}$ along the Sufichay River in the central area of the plain. Transmissivity value in the southwestern area is about $900 \mathrm{~m}^{2} / \mathrm{d}$. The minimum transmissivity occurs at the plain margin about $25 \mathrm{~m}^{2} / \mathrm{d}$. Groundwater level has annual cyclic variation depending on wet and dry seasons. The annual highest and lowest levels in the aquifer occur in May and September, respectively. The highest level is more than $1500 \mathrm{~m}$ above mean sea level (amsl) and decreases gradually towards a salt swamp less than $1280 \mathrm{~m}$ amsl (Fig. 3). The aquifer begins from north and east of the plain and continues to the west. The western limit of the aquifer is a salt swamp that contains fine grain lacustrine sediments with low hydraulic conductivity. The salt swamp may act as a barrier to restrict hydraulic connection between the aquifer and Urmia Lake. The general direction of groundwater flow is from north and east to southwest and west toward Urmia Lake. The groundwater level is generally near ground surface (about $2 \mathrm{~m}$ below land surface) in the downgradient areas and the water quality is not suitable for agricultural use.

\section{Hydrochemical Framework}

\subsection{Data Collection}

Ninety (90) samples were collected from springs, qanats, and water wells distributed over the study area during July and September 2013. Location of the samples is shown in Fig. 1. The samples were collected in 1.01 clean plastic bottles. Prior to collection, the sample bottles were rinsed thoroughly with the sample water. The groundwater samples were analyzed in the

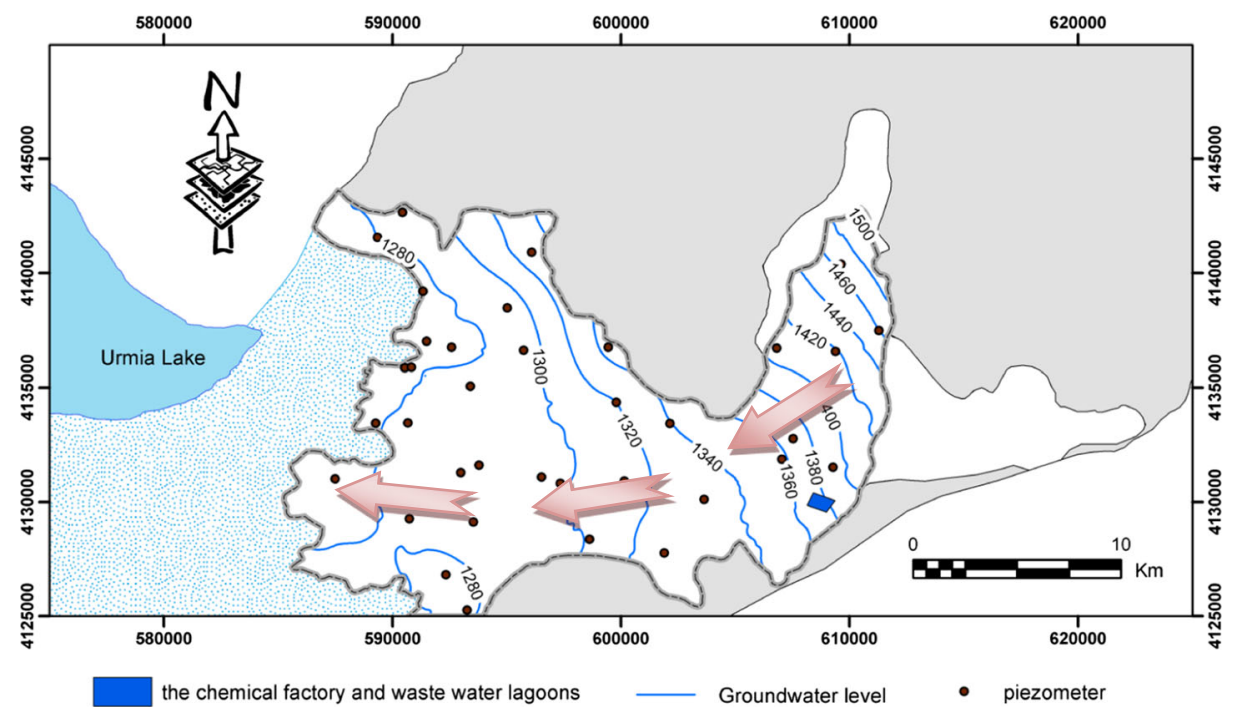

Fig. 3 Groundwater level contour map (2010) and location of wastewater lagoons (arrows show general flow path) 
hydrogeological laboratory at the University of Tabriz for many parameters such as $\mathrm{pH}$, electric conductivity (EC), bicarbonate $\left(\mathrm{HCO}_{3}{ }^{-}\right)$, chloride $\left(\mathrm{Cl}^{-}\right)$, sulfate $\left(\mathrm{SO}_{4}{ }^{2-}\right)$, calcium $\left(\mathrm{Ca}^{2+}\right)$, magnesium $\left(\mathrm{Mg}^{2+}\right)$, sodium $\left(\mathrm{Na}^{+}\right)$, potassium $\left(\mathrm{K}^{+}\right)$, and nitrate $\left(\mathrm{NO}_{3}{ }^{-}\right)$by standard methods (APHA, 1998). Total hardness (TH), total dissolved solid (TDS) and sodium absorption ratio (SAR) were calculated from the samples. A statistical summary of chemical parameters measured in 2013 from the groundwater samples is presented in Table 1.

The Maragheh-Bonab Plain has low TDS groundwater at the upgradient. However, there is a chemical factory in the south of the city of Maragheh (see Fig. 3), which produces $\mathrm{Na}_{2} \mathrm{CO}_{3}$ by the Solvay process via the reaction of $\mathrm{CaCO}_{3}, \mathrm{NaCl}$, and $\mathrm{CO}_{2}$ in the water. $\mathrm{Na}_{2} \mathrm{CO}_{3}$ ultimately precipitates as a solid. The principal byproduct of the process is $\mathrm{CaCl}_{2}$ in aqueous solution in large scale (Othmer 1978). Many unlined lagoons are formed to collect this byproduct as wastewater. The wastewater penetrates the groundwater system easily.

In order to compare groundwater quality before and after wastewater discharge, data were collected in the year 2000 which represent the typical groundwater condition of the MaraghehBonab Plain prior to the formation of these wastewater lagoons. Table 1 lists the mean values of physico-chemical parameters in the year 2000 indicating a dramatic increase in EC values and hydrochemical parameters from 2000 to 2013 due to the effect of these lagoons.

The Stiff diagram was used for investigating the influence of the lagoons on groundwater in downgradient of the plain. For this purpose, two samples (Eshratabad and Varjouy) in upgradient and two samples (Khoushemehr1 and Aghakhani) in downgradient of wastewater lagoons were sampled. The location of these samples has shown in the Fig. 1. Figure 4 shows Stiff diagrams of the selected samples for five consecutive years (2010-2014). Stiff diagrams of Eshratabad and Varjouy samples indicate that quality of groundwater is good and it has usual trend during these years. Stiff diagrams of the other pair of samples which are located near wastewater lagoons, show that concentration of chloride, calcium, and sodium in these samples are like wastewater and drastically high. This reveals an unusual increase of these ions is resultant of mixing large volume of wastewater with groundwater.

Table 1 Minimum, maximum, and mean values of physico-chemical parameters in 2013

\begin{tabular}{lllllll}
\hline Parameters & Unit & Min & Max & Mean & $\begin{array}{l}\text { Mean } \\
(2000)\end{array}$ & $\begin{array}{l}\text { WHO guideline } \\
\text { limit }(2009)\end{array}$ \\
\hline $\mathrm{pH}$ & & & & 7.95 & 7.60 & $6.5-8.5$ \\
$\mathrm{EC}$ & $\mu \mathrm{S} / \mathrm{cm}$ & 327 & 10,200 & 1825 & 1086 & \\
$\mathrm{TDS}$ & $\mathrm{mg} / \mathrm{L}$ & 214 & 6384 & 1150 & 782 & 500 \\
$\mathrm{Na}$ & $\mathrm{mg} / \mathrm{L}$ & 7.36 & 1127.00 & 164.40 & 95.20 & 200 \\
$\mathrm{~K}$ & $\mathrm{mg} / \mathrm{L}$ & 0.78 & 24.96 & 6.54 & 7.80 & \\
$\mathrm{Ca}$ & $\mathrm{mg} / \mathrm{L}$ & 43.60 & 760.00 & 147.18 & 72.00 & 75 \\
$\mathrm{Mg}$ & $\mathrm{mg} / \mathrm{L}$ & 8.60 & 180.40 & 49.80 & 35.20 & 30 \\
$\mathrm{Cl}$ & $\mathrm{mg} / \mathrm{L}$ & 3.55 & 3088.50 & 273.80 & 63.90 & 250 \\
$\mathrm{HCO}$ & $\mathrm{mg} / \mathrm{L}$ & 183.00 & 1156.56 & 442.64 & 353.80 & \\
$\mathrm{SO}_{4}$ & $\mathrm{mg} / \mathrm{L}$ & 19.20 & 1449.60 & 373.14 & 297.60 & 250 \\
$\mathrm{NO}_{3}$ & $\mathrm{mg} / \mathrm{L}$ & 1.13 & 53.88 & 11.21 & & 50 \\
$\mathrm{TH}$ & $\mathrm{mg} / \mathrm{L} \mathrm{CaCO}$ & 230.02 & 3723.54 & 1048.64 & 325.46 & \\
$\mathrm{SAR}$ & - & 0.27 & 11.13 & 2.71 & 2.60 & \\
\hline
\end{tabular}




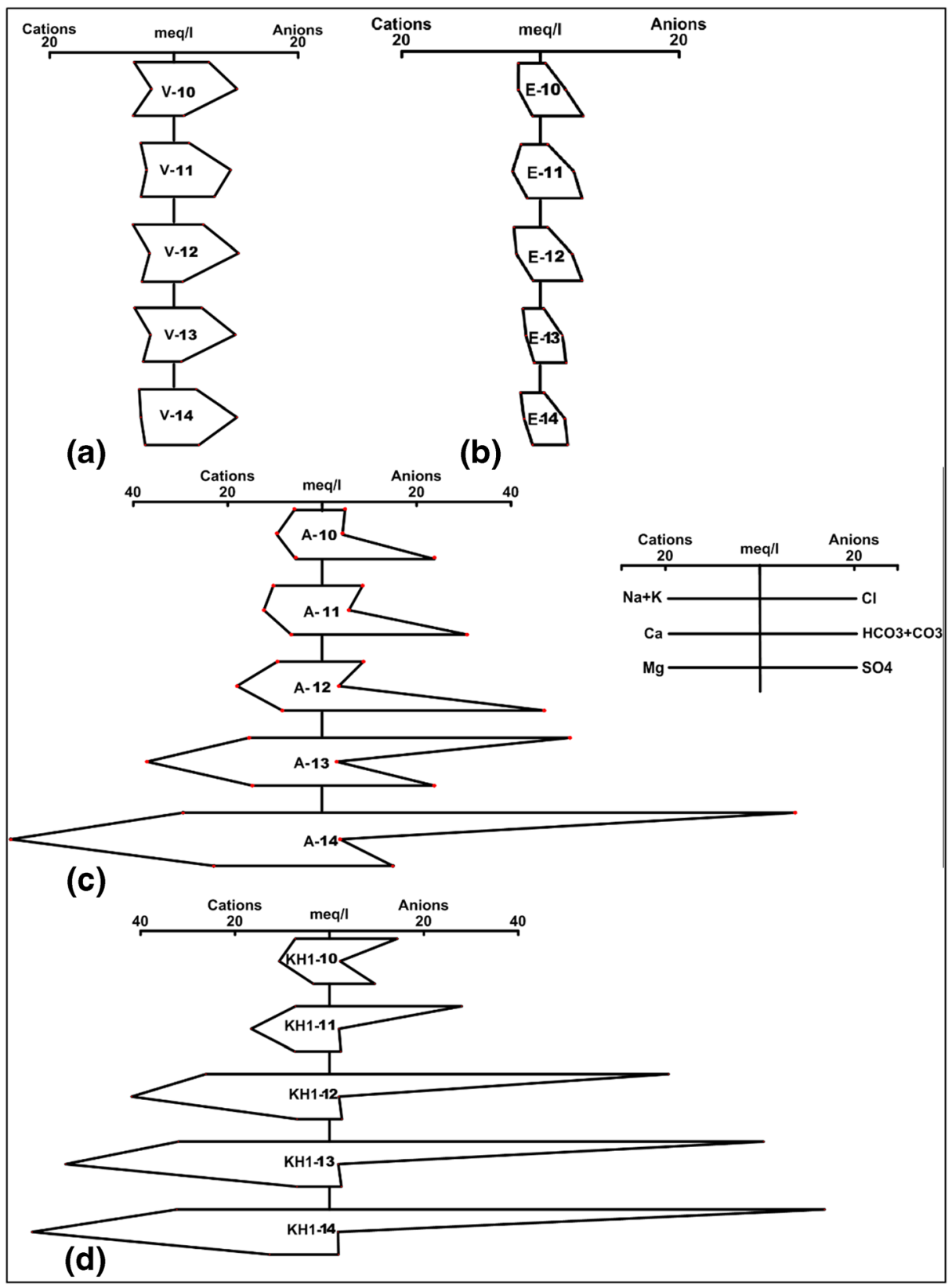

Fig. 4 Stiff diagrams of the selected samples for five consecutive years (2010-2014)

\subsection{Groundwater Types}

The graphical methods are used to facilitate the interpretation and presentation of the chemical analysis (Schwartz and Zhang 2003). In addition to displaying and comparing the analyses, graphical methods were devised to help to detect and identify mixing of waters of different 
compositions (Hem 1986). The common technique for plotting water data is the Piper (1944) diagram that is used to deduce groundwater types (Hounslow 1995). In this study, a Piper trilinear diagram is constructed to display the relative concentrations of different ions from individual water samples of the study area. Groundwater types reflect the effects of chemical reactions occurring between the minerals within the lithologic framework and the groundwater. Figure 5 shows that groundwater falls into the category of $\mathrm{Ca}-\mathrm{HCO}_{3}$ water type in northern and eastern areas of the aquifer (upgradient area). $\mathrm{Na}-\mathrm{Cl}$ water type is in the western area of the aquifer and at the edge of Urmia Lake due to the salt swamps and the outflow of groundwater.

Most of the samples that were taken from northern areas (upgradient zone), fall into zone 5 in the Piper diagram which represents freshwater with temporary hardness (see Fig. 5). There are a few samples in zone 7 (see Fig. 5), which is characterized as a saline water zone. Groundwater quality of the samples around the outlet of the plain changes to the $\mathrm{Cl}^{-}$water type. The affected groundwater samples by waste water of lagoons lies in the zone 6 (see Fig. 5). In these samples, $\mathrm{Cl}^{-}$and $\mathrm{Ca}^{2+}$ are increased unusually, which indicates contaminated water. The rest of the samples fall into zone 9 (see Fig. 5) and they are located in the central parts of the plain. In this zone, there is no dominant ion.

\subsection{Hydrochemical Evolution}

Groundwater chemistry evolves by many complex geological, hydrogeological, geochemical and climatic factors. The chemical constituents of groundwater tend to increase with the length of its flow paths as well as total dissolved solids. Groundwater evolves chemically from

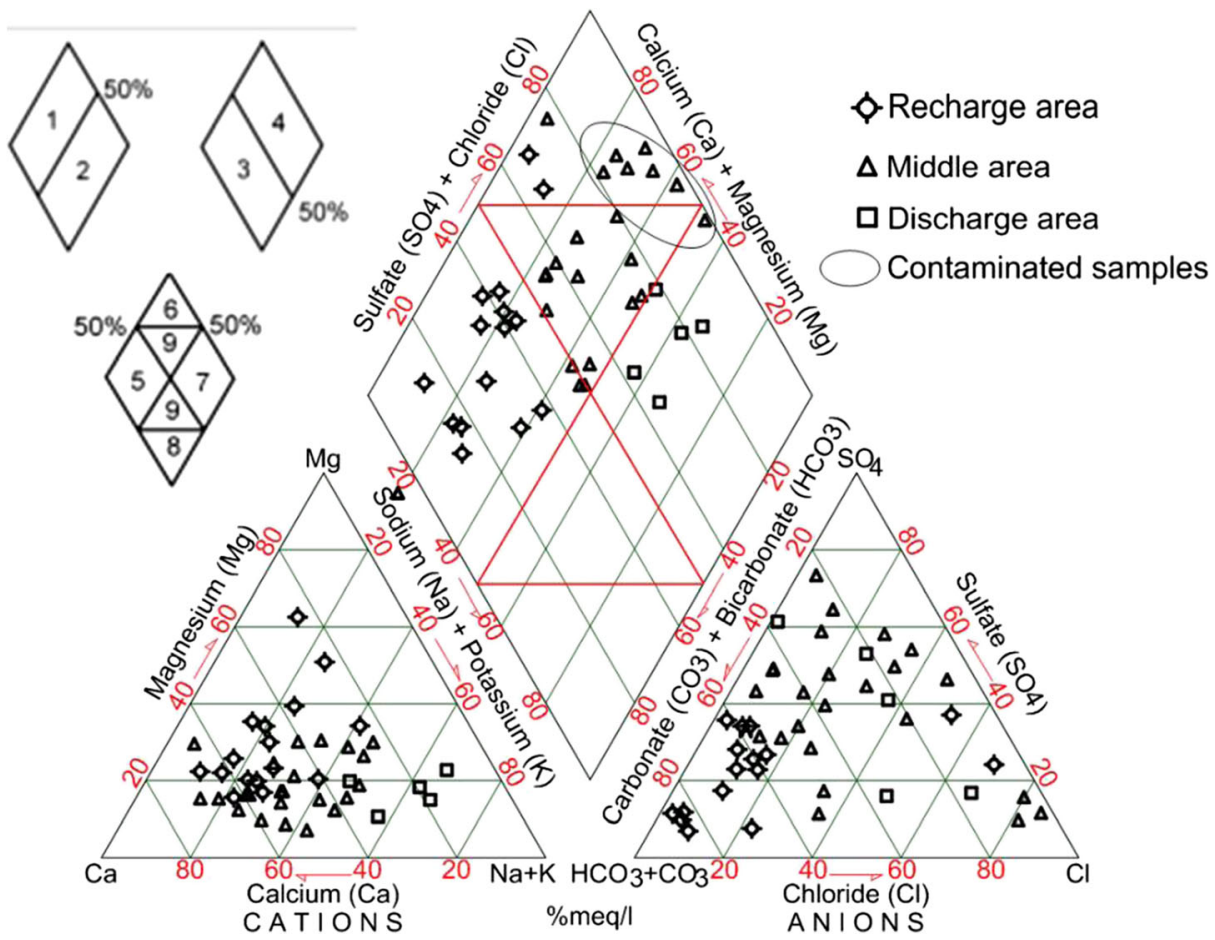

Fig. 5 Piper diagram of the groundwater samples and nine piper zones 
$\mathrm{HCO}_{3}{ }^{-}$type towards high $\mathrm{Cl}^{-}$composition (Chebotarev 1955; Freeze and Cherry 1979). Increases in $\mathrm{Cl}$ and $\mathrm{SO}_{4}{ }^{2-}$ concentrations in groundwater are a result of gradual dissolution of halite or gypsum contained in rocks along the flow path, gradual $\mathrm{Ca}-\mathrm{Mg}$ ion exchange, or dedolomitization (Mazor et al. 1993). In order to investigate water quality changes in the entire natural groundwater system, groundwater evolution along the flow path is used as a means of characterizing the groundwater quality and to recognize changes in inputs influenced by pollution from general natural trends in waters. The graphical methods were developed to display the chemical composition of the main components in groundwater at a glance (Appelo and Postma 2005). For this purpose, a pie diagram map in Fig. 6 is produced to show the distribution of water chemistry in the plain. In the pie diagram, the size of a circle is proportional to the amount of the total dissolved solids. As a result, waters with a similar chemical composition are quickly recognized. As shown in Fig. 6, the quality of groundwater decreases gradually from Sahand Mountain (upgradient area) toward the downgradient area due to increasing residence time. Furthermore, flatness of the ground surface, shallow depth of the groundwater, and a boundary of silt and clay at the outlet of groundwater flow from the aquifer created salt swamps in the western part of the plain that decrease the quality of groundwater in this area. However, as shown in Fig. 6, groundwater in the middle area of the plain is influenced by the contaminated water from drainage of the wastewater lagoons. The wastewater discharges to the plain without treatment along the groundwater path shown in Fig. 3.

The study of groundwater in the Maragheh-Bonab Plain aquifer revealed a wide range of concentrations of different compositions. The composition diagrams shown in Fig. 7 produce an evolutionary picture for $\mathrm{Na}, \mathrm{Ca}, \mathrm{Mg}$, and $\mathrm{Cl}$ from upgradient to downgradient area. The $\mathrm{Na}$, $\mathrm{Mg}$, and $\mathrm{Cl}$ concentrations increase with increasing total dissolved ions (TDI). Figure 7a-d explain the dissolution of $\mathrm{NaCl}$. The $\mathrm{Ca}$ concentration in Fig. $7 \mathrm{~b}$ increases as the $\mathrm{Na}$ concentration increases for low and moderate TDI, but decreases at higher TDI, largely in

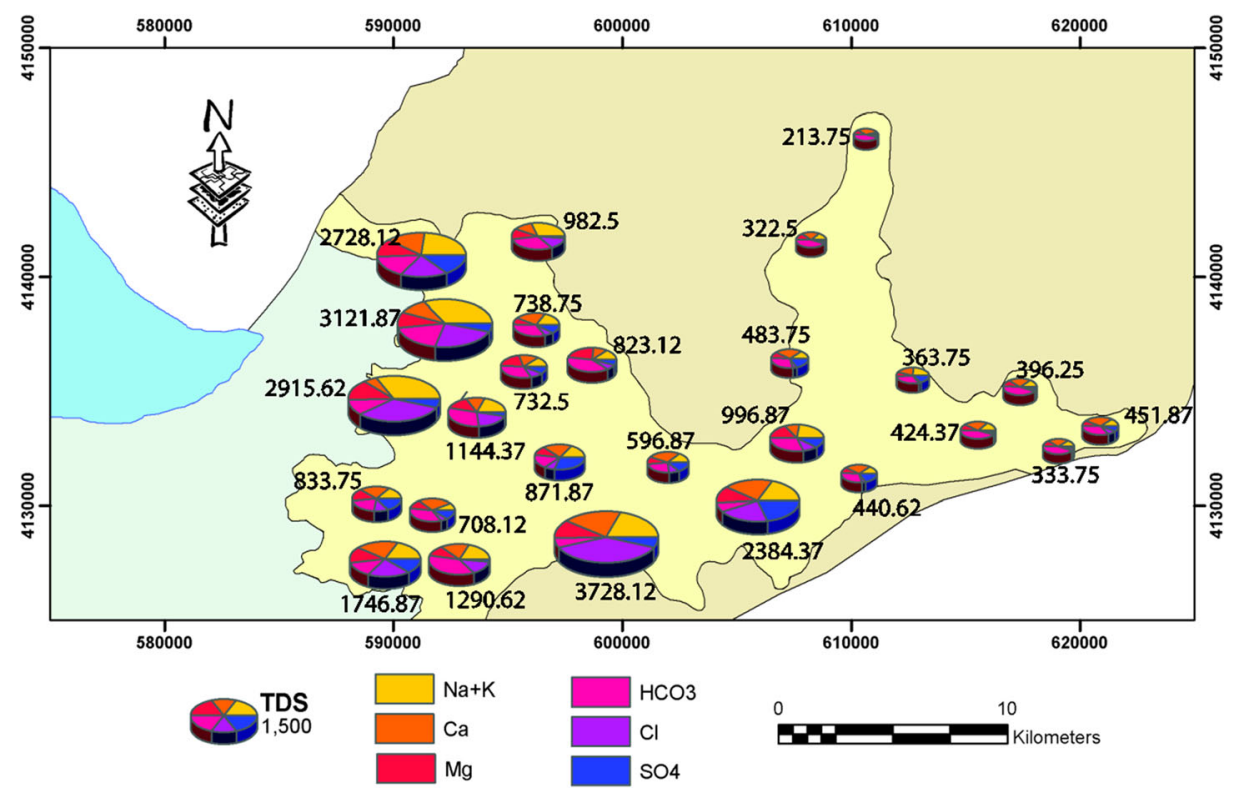

Fig. 6 Pie diagram map of the groundwater samples 


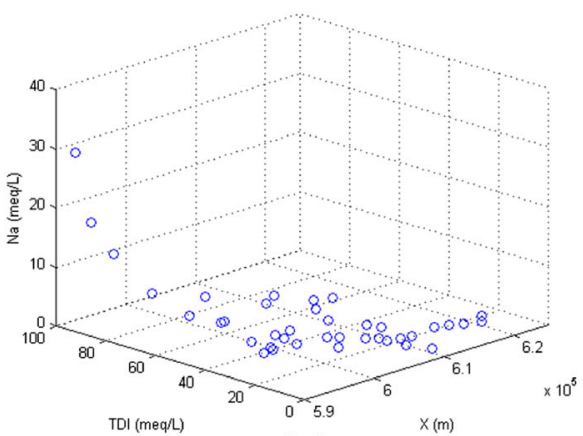

(a)

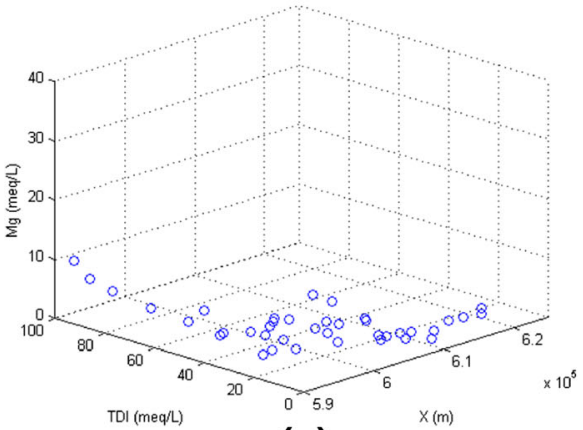

(c)

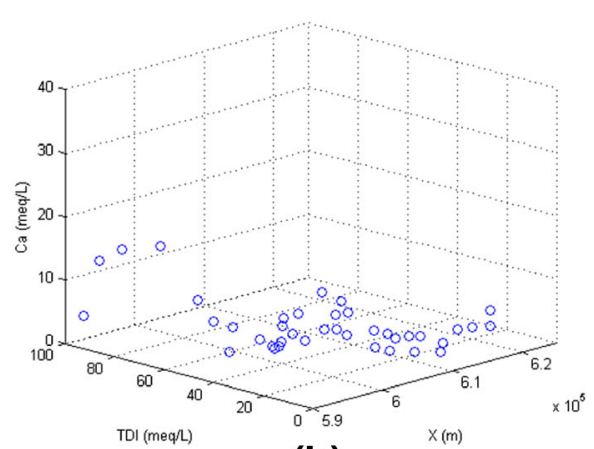

(b)

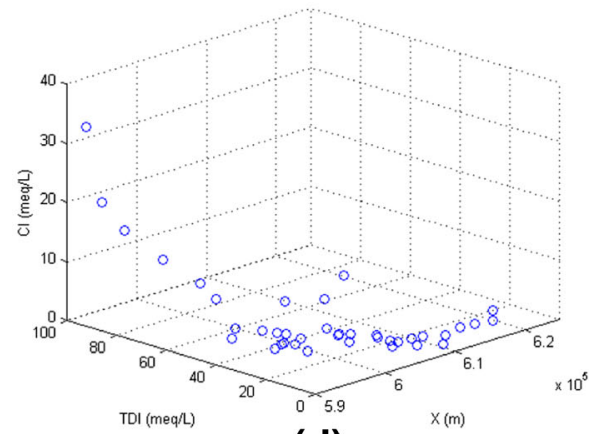

(d)

Fig. 7 Compositional diagrams of groundwater samples (upgradient to downgradient area)

the downgradient area. This may be the result of the increase in the $\mathrm{NaCl}$ dissolution and the decrease of calcite dissolution or ion exchange effect. In summary, concentration of the ions rises toward the downgradient area as TDI increases. This is due to the decrease of grain size of sediments near Urmia Lake, the shallow groundwater level, the increase in evaporation compared to other areas in the plain, and due to the salt swamp water.

\subsection{Hydrochemical Processes}

The main processes contributing to chemical compositions in groundwater of the study area are the dissolution along the flow path, the mixing with groundwater in the downgradient area, the ion exchange reactions, and the mixing with wastewater. These geochemical processes are responsible for the seasonal and spatial variations in groundwater chemistry (Matthess and Harvey 1982; Kumar et al. 2006).

Figure. 8 shows a scatter plot of $\mathrm{Ca}+\mathrm{Mg}$ versus $\mathrm{HCO}_{3}+\mathrm{SO}_{4}$ for the samples. The solid line in the figure represents a 1:1 relation. The samples on the line with $\mathrm{HCO}_{3}+\mathrm{SO}_{4}$ concentrations less than $10 \mathrm{meq} / \mathrm{Lmeq} / \mathrm{L}$ are related to the upgradient area where calcite dissolution has occurred. Beyond $10 \mathrm{meq} / \mathrm{L}$ concentration, the samples near the line are in the middle areas of the plain, showing the gypsum dissolution (Jankowski et al. 1998). The groundwater in these areas has a distinctly higher calcium and sulfate concentrations, which are attributed to the dissolution of gypsum $\left(\mathrm{CaSO}_{4} \cdot 2 \mathrm{H}_{2} \mathrm{O}\right)$. In Fig. 8, few samples have $\mathrm{Ca}+$ $\mathrm{Mg}$ concentrations significantly exceeding the $\mathrm{HCO}_{3}+\mathrm{SO}_{4}$ concentrations. The increase in $\mathrm{Ca}$ 
Fig. 8 A scatter plot of $\mathrm{Ca}+\mathrm{Mg}$ versus $\mathrm{SO}_{4}+\mathrm{HCO}_{3}$

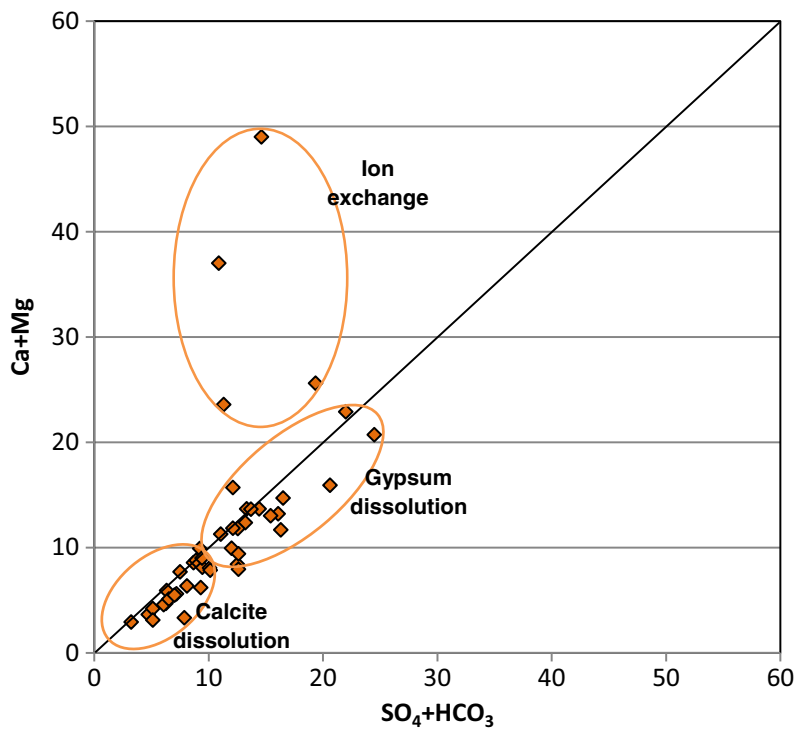

and $\mathrm{Mg}$ concentrations may have been caused by several hydrochemical processes, such as the ion exchange, the reduction of sulfates, or a combination of both processes (Al-Bassam 1998). Since there is no indication of reduction processes in the study area, it is more likely that the influencing process is the ion exchange.

In the aquifer containing both dolomite and calcite, dissolution of gypsum causes the dedolomitisation process due to precipitation of calcite and dissolution of dolomite (Plummer et al. 1990; Appelo and Postma 2005). By dissolution of gypsum, the calcium concentration increases, causing calcite to precipitate. This lowers the aqueous carbonate concentration and causes dolomite to dissolve. In the middle areas of the aquifer, dedolomitisation may be an important geochemical process in the groundwater system. As shown in Fig. 9, an increase in the sulfate concentration in groundwater increases magnesium and calcium concentrations and decreases bicarbonate concentration.

Assuming that all the $\mathrm{Cl}$ comes from the dissolution of $\mathrm{NaCl}$, a scatter diagram of $\mathrm{Ca}+\mathrm{Mg}$ $\mathrm{SO}_{4}-\mathrm{HCO}_{3}$ versus $\mathrm{Na}-\mathrm{Cl}$ was plotted in Fig. 10 to show ion exchange in the aquifer system. The concentration difference in $\mathrm{Na}-\mathrm{Cl}$ close to zero indicates groundwater that is not affected

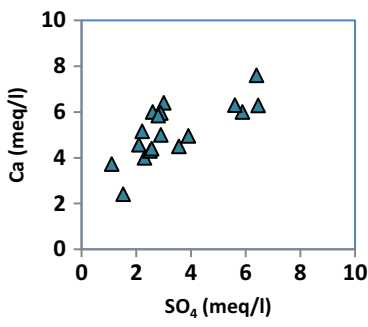

(a)

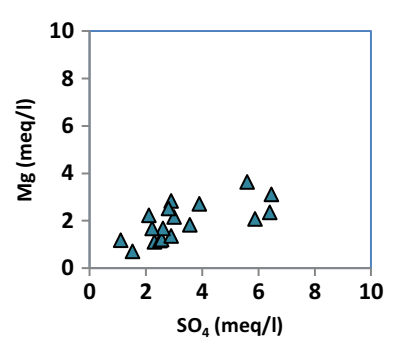

(b)

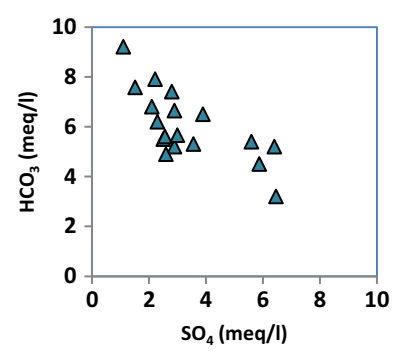

(c)

Fig. 9 Scatter plots of calcium, magnesium, and bicarbonate concentrations versus sulfate concentration for the samples in the middle areas of the plain 
Fig. 10 Scatter plot of $[\mathrm{Ca}]+[\mathrm{Mg}]-\left[\mathrm{SO}_{4}\right]-\left[\mathrm{HCO}_{3}\right]$ versus $[\mathrm{Na}]-[\mathrm{Cl}]$

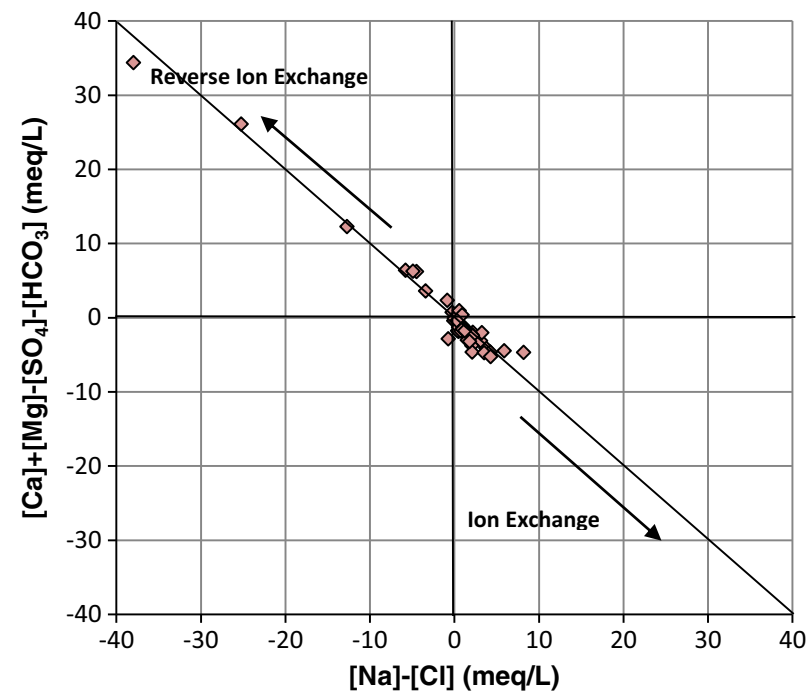

by ion exchange. If the ion exchange occurs, samples would be on the straight line with a slope of -1 (Jankowski et al. 1998). The samples plotted close to the reverse ion exchange in Fig. 10 belong to the samples near the wastewater lagoons and salt swamps in the downgradient area. In the downgradient area, the existence of clay minerals and mixing of groundwater with salt swamps water provide this process. In the wastewater disposal area, the high amount of $\mathrm{Ca}$ in the wastewater area is due to the release of $\mathrm{Ca}$ from the wastewater lagoons; but, in Fig. 10, it appears as a reverse ion exchange.

\subsection{Water Quality Index}

According to the $\mathrm{WHO}$, about $80 \%$ of all the diseases in human beings are caused by water. Once the groundwater is contaminated, its quality cannot be restored by stopping the pollutants from the source. It, therefore, becomes imperative to regularly monitor the quality of groundwater and to devise ways and means to protect it. Water quality index (WQI) is one of many effective tools to communicate information on the quality of water (Tiwari and Mishra 1985; Singh 1992; Subba Rao 1997; Mishra and Patel 2001; Naik and Purohit 2001). As such, it is an important indicator for the assessment and management of groundwater. WQI is defined as a rating reflecting the composite influence of different water quality parameters (Sahu and Sikdar 2008). WQI is calculated based on the suitability of groundwater for human consumption.

For computing WQI three steps are followed (Tiwari and Mishra 1985; Singh 1992). In the first step, a weight $\left(w_{i}\right)$ is assigned to each water quality parameter according to its relative importance in the overall quality of water for drinking purposes. Then, the relative weight $\left(W_{i}\right)$ is computed by Eq (1) as follows (Singh 1992):

$$
W_{i}=\frac{w_{i}}{\sum_{i=1}^{n} w_{i}}
$$


where $n$ is the number of parameters. In the second step, a quality rating $\left(q_{i}\right)$ is calculated for each parameter as the ratio of its concentration to its respective standard value according to the guidelines from the WHO ( 2009):

$$
q_{i}=\left(\frac{C_{i}}{S_{i}}\right) \times 100
$$

where $C_{i}$ is the concentration of each chemical parameter in each water sample in $\mathrm{mg} / \mathrm{L}$, and $S_{i}$ is the WHO drinking water standard for each chemical parameter in $\mathrm{mg} / \mathrm{L}$. In the third step, the WQI is computed as follows (Tiwari and Mishra 1985):

$$
\mathrm{WQI}=\sum_{i=1}^{n} W_{i} q_{i}
$$

The WQI values are classified into five categories as listed in Table 2. In the study area, the computed WQI values range from 25.45 to 194.35 . Among the groundwater samples $22 \%$ fall in the category of "excellent water", about $58 \%$ of groundwater samples fall in the category of "good water", and $20 \%$ of the groundwater samples are in "poor" quality. The WQI map shown in Fig. 11 is produced by a kriging interpolation algorithm to display the spatial distribution of the water quality categories. The "excellent water" covers $86 \mathrm{~km}^{2}$. A majority of the area is occupied by the "good water" and it covers about $200 \mathrm{~km}^{2}$. The groundwater samples show "poor water" over an area of $45 \mathrm{~km}^{2}$, approximately. Figure 11 shows that the "good water" area is in an intermediate position between the "excellent water" and "poor water". The distribution pattern of groundwater indicates that the evolution of the "blended" water is possibly due to the hydraulic mixing of "excellent" and "poor" waters within the aquifer. The quality of groundwater decreases gradually from Sahand mountain hills (highlands) toward salt swamps in the eastern edge of Urmia Lake (with TDS about $300 \mathrm{~g} /$ L). However, there are a few areas showing "poor water" in the south of the plain. These areas are affected by the wastewater lagoons, where wastewater discharges to the plain without treatment.

\section{Conclusions}

From the hydrogeological perspective, permeable formations of the Maragheh-Bonab Plain mainly consist of Quaternary alluvial sediments and rarely fractured rocks like Permian limestone. Groundwater level, whose fluctuation is affected by climate characteristics and cyclic wet and dry seasons over the years, has an annual regular variation in this unconfined aquifer. Four major groundwater types are identified using the Piper diagram. The Ca-Mg-

Table 2 Categories for water quality index

\begin{tabular}{ll}
\hline WQI & Category \\
\hline below 50 & excellent water \\
$50-100$ & good water \\
$100-200$ & poor water \\
$200-300$ & very poor water \\
above 300 & unsuitable for drinking \\
\hline
\end{tabular}




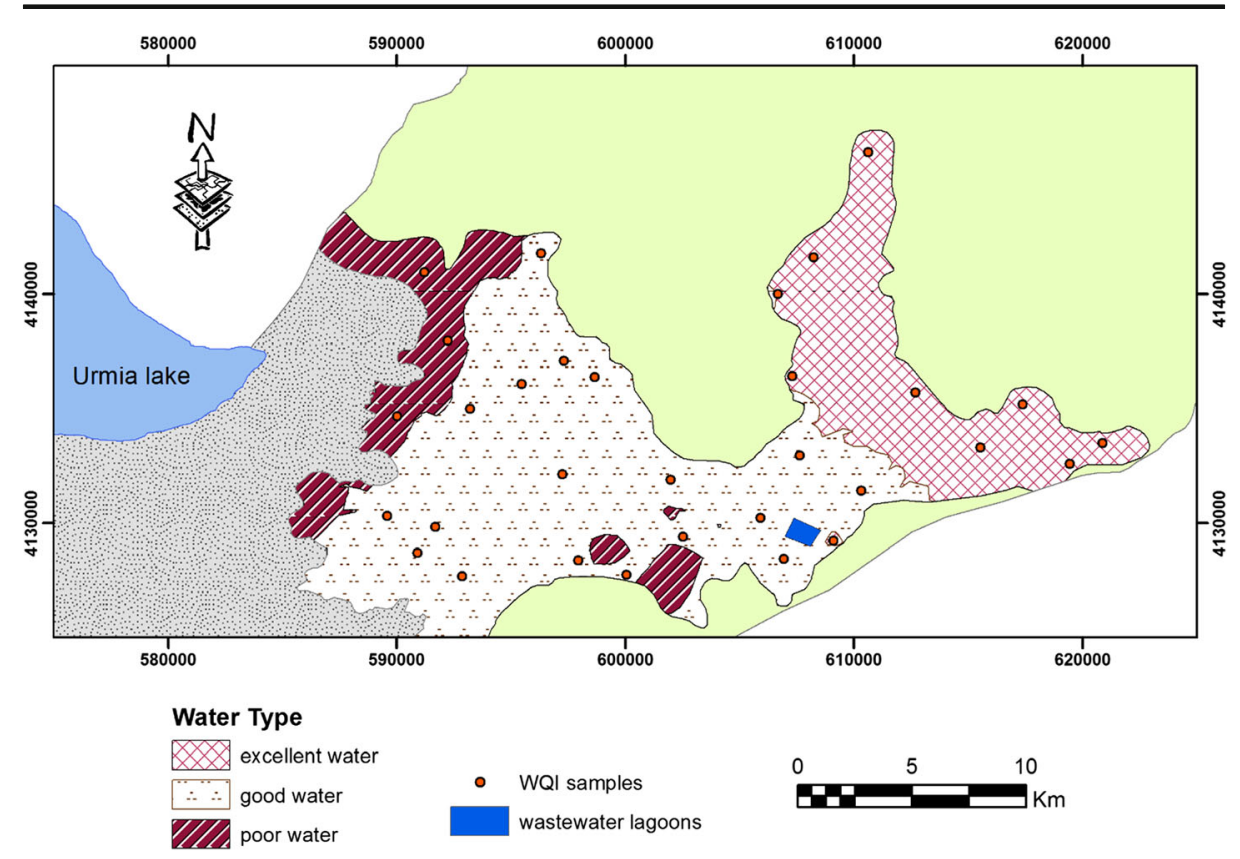

Fig. 11 Water quality index map

$\mathrm{HCO}_{3}$ water type represents more than $60 \%$ of the groundwater in the Maragheh-Bonab Plain. The $\mathrm{Na}-\mathrm{Cl}$ water type comprises less than $18 \%$ of the groundwater and it is mainly associated with Urmia Lake. There are a few groundwater samples with dramatic increase in $\mathrm{Cl}^{-}$and $\mathrm{Ca}^{2+}$, that indicates contaminated effect of waste water lagoons. There are no dominant cations and anions in the other water type.

The results of the pie diagram map and the compositional graphs show a typical trend in the groundwater quality due to increasing residence time from the upgradient to the downgradient area. Results also confirmed the anomalies in water chemistry in the plain caused by industrial wastewater. In the downgradient area, the groundwater quality decline is due to the decrease in grain size of sediments near Urmia Lake, shallow groundwater level, and the increase in evaporation comparing to other areas in the plain. The scatter plots of $\mathrm{Ca}+\mathrm{Mg}$ versus $\mathrm{HCO}_{3}+\mathrm{SO}_{4}$ and $\mathrm{Ca}+\mathrm{Mg}-\mathrm{SO}_{4}-\mathrm{HCO}_{3}$ versus $\mathrm{Na}-\mathrm{Cl}$ indicate that the main processes contributing to the chemical compositions in groundwater are the dissolution along the flow path, gypsum dissolution, dedolomitisation, ion exchange reactions, and the mixing with wastewater.

The computed water quality index (WQI) ranges from 25.45 to 194.35 thereby categorizing the groundwater of the plain aquifer into "excellent water," "good water," and "poor water". There is an obvious similarity between the spatial distribution of the WQI and hydrochemical water types in the Piper diagram. The "excellent" quality water largely coincides with the Ca$\mathrm{Mg}-\mathrm{HCO}_{3}$ water type. The "poor" water matches with the $\mathrm{Na}-\mathrm{Cl}$ water type, and the "good" quality water coincides with blended water that is located between two other water types. Most of the groundwater samples in northern and eastern areas of the aquifer (upgradient area) are of the $\mathrm{Ca}-\mathrm{HCO}_{3}$ type and are suitable for domestic and irrigation use. In the western area of the aquifer, close to Urmia Lake, higher concentrations of hydrochemical ions are observed. 
It is recommended to discharge wastewater into the Urmia Lake. Considering the water shortage of the lake during recent years, water transfer can be helpful to revive the drying lake. It would not add additional harmful environmental effect because the lake water already has large TDS (at least two times more than wastewater) and there is no sign of any toxic content or heavy metals in the wastewater. It is highly recommended to insulate the lagoons before making any managerial decision.

Acknowledgments The authors would like to thank the East Azerbaijan Regional Water Authority for providing an access to their data.

\section{References}

Acheampong SY, Hess JW (1998) Hydrogeologic and hydrochemical framework of the shallow groundwater system in the southern Voltaian Sedimentary Basin, Ghana. Hydrogeology Journal 6:527-537

Alavi M, Shahrabi M (1978) Geologic map of Maragheh 1: 100000. Geological Survey of Iran, Tehran

Al-Bassam AM (1998) Determination of hydrochemical processes and classification of hydrochemical facies for the Sakakah aquifer, northeastern Saudi Arabia. J African Earth Sci 27(1):27-38

APHA (American Public Health Association) (1998) Standard method for the examination of water and wastewater. 17th edition. Washington, DC

Appelo CAJ, Postma D (2005) Geochemistry, groundwater and pollution, 2nd edn. A.A. Balkema Publishers, Netherlands

Asghari Moghaddam A, Fijani E (2009) Hydrogeologic framework of the Maku area basalts, northwestern Iran. Hydrogeology Journal 17:949-959

Berberian M, King GCP (1981) Towards paleogeography and tectonic evolution of Iran. Earth Science 18(2): 210-262

Campbell BG, Amini MH, Bernor RL, Dickinson W, Drake R, Morris R, van Couvering JA, van Couvering JAH (1980) Maragheh: a classical late Miocene vertebrate locality in northwestern Iran. Nature 287:837-841

Chebotarev I (1955) Metamorphism of natural water in the crust of weathering. Geochimica et Cosmochimica Acta 8:22-212

Cloutier V, Lefebvre R, Therrien R, Savard MM (2008) Multivariate statistical analysis of geochemical data as indicative of the hydrogeochemical evolution of groundwater in a sedimentary rock aquifer system. J Hydrol 353(3-4):294-313

Dragon K (2006) Application of factor analysis to study contamination of a semi-confined aquifer (Wielkopolska buried valley aquifer, Poland). Journal of Hydrology 331(1-2):272-279

Dunnette DA (1979) A geographically variable water quality index used in Oregon. Journal of the Water Pollution Control Federation 51(1):53-61

Fijani E, Nadiri A, Asghari Moghaddam A, Tsai FT-C, Dixon B (2013) Optimization of DRASTIC method by supervised committee machine artificial intelligence to assess groundwater vulnerability for MaraghehBonab plain aquifer, Iran. J Hydrol 503:89-100

Freeze R, Cherry J (1979) Groundwater. Prentice-Hall, Englewood Cliffs, New Jersey, USA

Hem (1986) Study and interpretation of the chemical characteristics of natural water. U.S. Geological survey, Water Supply Paper 2254

Hossain G, Howladar MF, Nessa L, Ahmed SS, Quamruzzaman C (2010) Hydrochemistry and classification of groundwater resources of Ishwardi municipal area, Pabna District, Bangladesh. Geotechnical and Geological Engineering 28(5):671-679

Hounslow AW (1995) Water quality data: analysis and interpretation. Lewis Publisher, USA

Huang SB, Han ZT, Zhao L, Kong XK (2015) Hydrochemistry indicating groundwater contamination and the potential fate of chlorohydrocarbons in combined polluted groundwater: a case study at a contamination site in North China. Bulletin of Environmental Contamination and Toxicology 94(5):589-597

Jankowski J, Acworth RI, Shekarforoush S (1998) Sources of salinity in the Kyeamba Valley: implications for the agricultural productivity due to the impact of $\mathrm{Na}-\mathrm{Cl}$ rich groundwaters. In: weaver TR, Lawrence CR(eds) Proc Int groundwater Conf groundwater. Sustainable Solutions, University of Melbourne, Australia, pp. 287-292 
Jiang Y, Wu Y, Groves C, Yuan D, Kambesis P (2009) Natural and anthropogenic factors affecting the groundwater quality in the Nandong karst underground river system in Yunan, China. J Contaminant Hydrol 109:49-61

Kortatsi BK (2007) Hydrochemical framework of groundwater in the Ankobra Basin, Ghana. Aquatic Geochemistry 13:41-74

Kumar M, Ramanathan AL, Rao MS, Kumar B (2006) Identification and evaluation of hydrogeochemical processes in the groundwater environment of Delhi, India. J Environ Geol 50:1025-1039

Matthess G, Harvey JC (1982) The properties of groundwater. John Wiley \& Sons Inc, U.S.A.

Mazor E, Drever JI, Fineley J, Huntoon PW (1993) Hydrochemical implication of groundwater mixing: an example from the southern Laramie basin, Wyoming. Water Resources Res 29(1):193-205

Mishra PC, Patel RK (2001) Study of the pollution load in the drinking water of Rairangpur, a small tribal dominated town of North Orissa. Indian J Environ Ecoplanning 5(2):293-298

Morgenstern U, Daughney CJ, Leonard G, Gordon D, Donath F, Reeves R (2015) Using groundwater age and hydrochemistry to understand sources and dynamics of nutrient contamination through the catchment into Lake Rotorua, New Zealand. Hydrol Earth Syst Sci 19:803-822

Naik S, Purohit KM (2001) Studies on water quality of river Brahmaniin Sundargarh district, Orissa. Indian Journal of Environment and Ecoplanning 5(2):397-402

Othmer K (1978) Encyclopedia of chemical technology, vol Volume 1, Third edn. John Wiley \& Sons publications, U.S.A.

Piper AM (1944) A graphical procedure in the geochemical interpretation of water analyses. American Geophysics 25:914-923

Plummer LN, Busby JF, Lee RW, Hanshaw BB (1990) Geochemical modeling of the Madison aquifer in parts of Montana, Wyoming, and South Dakota. Water Resources Research 26:1981-2014

Rajankar PN, Tambekar DH, Wate SR (2011) Groundwater quality and water quality index at Bhandara District. Environmental Monitoring and Assessment 179:619-625

Ravikumar P, Venkatesharaju K, Somashekar RK (2010) Major ion chemistry and hydrochemical studies of groundwater of Bangalore south Taluk, India. Environmental Monitoring and Assessment 163:643-653

Sahu P, Sikdar PK (2008) Hydrochemical framework of the aquifer in and around East Calcutta wetlands, West Bengal. Indian Environmental Geology 55(4):823-835

Schwartz FW, Zhang H (2003) Fundamentals of ground water. John Wiley and Sons, U.S.A.

Singh DF (1992) Studies on the water quality index of some major rivers of Pune, Maharashtra. Proceedings of the Academy of Environmental Biology 1(1):61-66

Stocklin J (1968) Structural history and tectonics of Iran, a review. American Association of Petroleum Geologists Bulletin 52(7):1229-1258

Subba Rao N (1997) Studies on water quality index in hard rock terrain of Guntur district, Andhra Pradesh. India National Seminar on Hydrology of Precambrian Terrains and Hard Rock Areas:129-134

Tiwari TN, Mishra MA (1985) A preliminary assignment of water quality index of major Indian rivers. Indian J Environ Protect 5:276-279

Umar A, Umar R, Ahmad MS (2001) Hydrogeological and hydrochemical framework of regional aquifer system in Kali-ganga sub-basin, India. Environmental Geology 40(4-5):602-611

Umar R, Ahmed I, Alam F, Khan MM (2009) Hydrochemical characteristics and seasonal variations in groundwater quality of an alluvial aquifer in parts of central ganga plain, western Uttar Pradesh, India. Environmental Geology 58:1295-1300

Vasanthavigar M, Srinivasamoorthy K, Vijayaragavan K, Ganthi RR, Chidambaram S, Anandhan P, Manivannan R, Vasudevan S (2010) Application of water quality index for groundwater quality assessment: Thirumanimuttar sub-basin. India Environ Monitor Assess 171:595-609

Water and Soil consulting corporation (1975). Geoelectrical Survey of Maragheh (in Persian).

Water Resource Corporation of East Azarbaijan Province (1964) Report of groundwater resources studies in Maragheh area (in Persian).

WHO (World Health Organization) (2009). Guideline for drinking water quality. 